\title{
Diversity of green algae (Chlorophyta) from bromeliad phytotelmata in areas of rocky outcrops and "restinga", Bahia state, Brazil
}

\author{
Geraldo José Peixoto Ramos ${ }^{1,3}$, Carlos Eduardo de Mattos Bicudo ${ }^{2}$ \& Carlos Wallace do Nascimento Moura ${ }^{1}$
}

\begin{abstract}
A floristic survey for green algae (Chlorophyta) from bromeliad phytotelmata of areas of rocky outcrop (Serra da Jibóia) and "restinga" (Parque das Dunas), Bahia state, Brazil is presented here. A total of twenty-three taxa were identified, including three species (Asterococcus superbus, Gongrosira papuasica and Lagerhemia chodatti) that are newly reported for Brazil and two Oedogonium species (Oedogonium pulchrum and O. areschougii) that were recollected in Brazilian territory after 115 years.
\end{abstract}

Key words: Bromeliaceae, microcosm, morphology, phytotelm, taxonomy.

\section{Resumo}

O presente estudo refere-se ao levantamento das espécies de algas verdes (Chlorophyta) ocorrentes em ambientes fitotelmatas bromelícolas de áreas de afloramentos rochosos (Serra da Jibóia) e restinga (Parque das Dunas), Bahia, Brasil. Foram identificados 23 táxons incluindo três espécies (Asterococcus superbus, Gongrosira papuasica e Lagerhemia chodatti) que estão sendo registradas pela primeira vez para o Brasil e duas espécies de Oedogonium (Oedogonium pulchrum and O. areschougii) que foram novamente coletadas para o Brasil após 115 anos.

Palavras-chave: Bromeliaceae, microcosmo, morfologia, fitotelmo, taxonomia.

\section{Introduction}

Bromeliaceae Family is one of the main components of the Neotropical flora, and their leaves disposition forming small reservoirs allow accumulation of rain water favoring development of a microcosm known as phytotelmata, composed of several associated organisms (Picado 1913; Varga 1928). Due to their water retention capacity and the complex and diverse architecture of their leaves, bromeliad tanks are well-known biodiversity magnifiers (Rocha et al. 1997). Besides the number of leaves, the main elements of the plant architecture such as diameter, height and volume directly affect the richness and abundance of organisms associated to it (Lawton 1983; Oliveira $\&$ Rocha 1997). Thus, the greater the complexity of the leaves' architecture of a bromeliad, the higher will be the interaction between these organisms.

Taxonomic and ecological studies of algae from such environments are scarce, so that reports of the occurrence of green algae in bromeliad tanks are rather rare (Hernández-Rodríguez et al. 2014) and the identification of these algae is usually restricted to the genus level (Laessle 1961; Brouard et al. 2011; Killick et al. 2014). One of the few reports on the importance of this group in the phytotelmata community is that of Carrias et al. (2014) conducted in French Guiana, in which Chlorophyta contributed with $90 \%$ to total algal biomass in Aechmea aquilega (Salisbury) Grisebach tanks.

Floristic studies aiming at the chlorophytes in bromeliad phytotelmata are inexistent. The few records of the occurrence of green algae in this type of environment in Brazil were reported by Lyra (1976), who cited some chlorophytes in bromeliad from Pernambuco state; Nogueira (1991) that reported the first occurrence of Scotiellopsis terrestris (Reisigl) Puncochárová \& Kalina [= Coelastrella terrestris (Reisigl) Hegewald \& N.Hanagata] for phytotelmata environment in tropical region; and Sophia (1999) that conducted a taxonomic survey of the desmids and some other algal groups, including eight chlorophytes.

\footnotetext{
${ }^{1}$ Universidade Estadual de Feira de Santana, Prog. Pós-graduação em Botânica, Av. Transnordestina s/n, Novo Horizonte, 44036-900, Feira de Santana, BA, Brazil.

${ }^{2}$ Instituto de Botânica, Núcleo de Pesquisa em Ecologia, Av. Miguel Estéfano 3687, 04301-902, São Paulo, SP, Brazil.

${ }^{3}$ Author for correspondence: geraldojpr@gmail.com
} 
To improve understanding of the algal flora of phytotelmata environments in Brazil, present study aimed at carrying a floristic survey of the green algae (Chlorophyta) occurring in bromeliad tanks from two areas of Bahia State, highlighting their morphological characteristics and environmental conditions.

\section{Material and Methods}

Study was carried out in two areas of Bahia state, northeast Brazil: Serra da Jibóia (Santa Teresinha) and Parque das Dunas (Salvador) (Fig. 1). Serra da Jibóia ( $\left.39^{\circ} 28^{\prime} \mathrm{W}, 12^{\circ} 51^{\prime} \mathrm{S}\right)$ is located in the eastern part of the Bahia state, made up
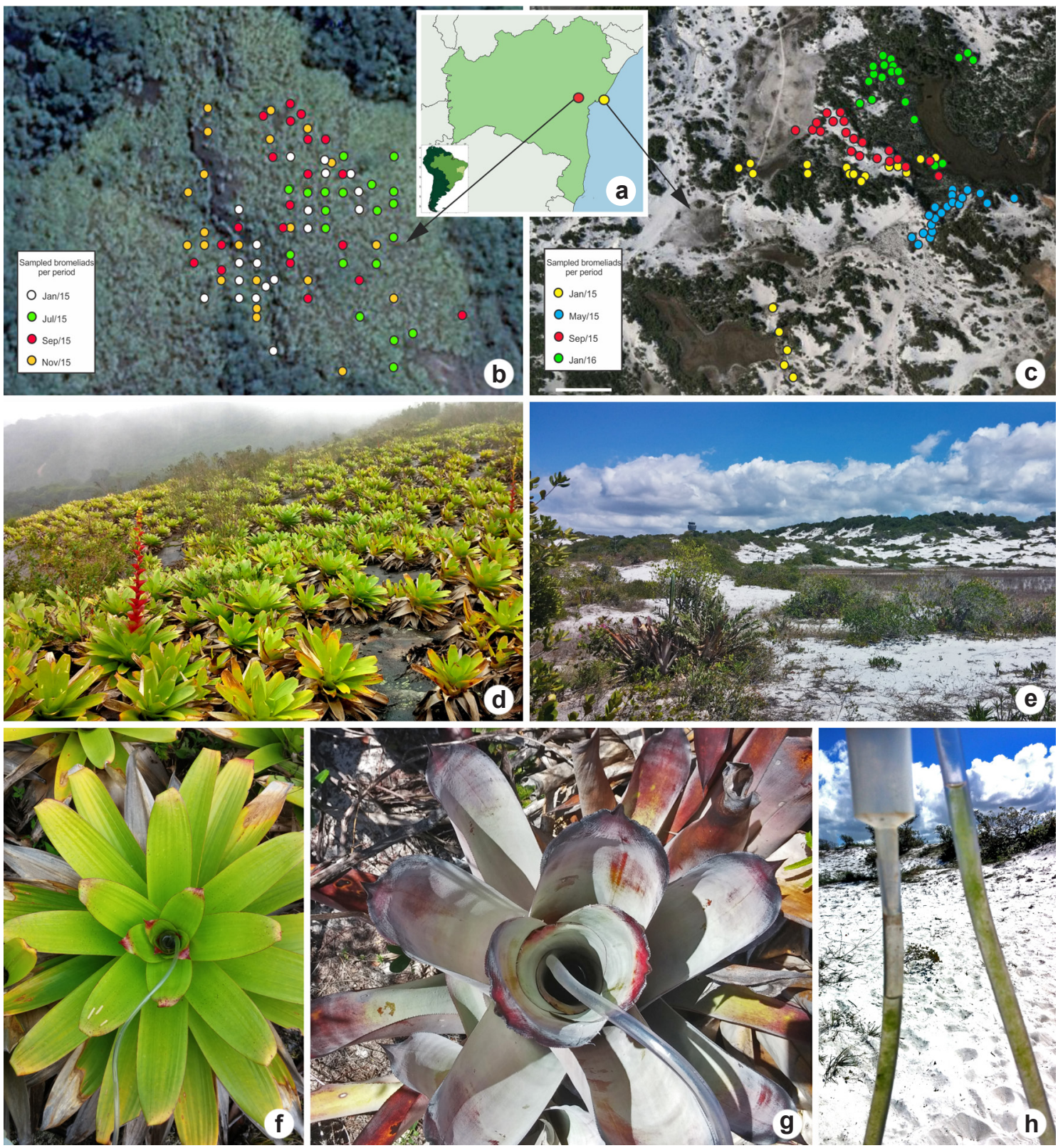

Figure 1 - a. Location of Serra da Jibóia (red dot) and Parque das Dunas (yellow dot) in the Bahia state, Brazil; b. Satellite image with distribution of sampled bromeliads in Serra da Jibóia; c. Satellite image with distribution of the sampled bromeliads in Parque das Dunas, Salvador; d. Overview of bromeliads on rocky outcrops of Serra da Jibóia; e. Overview of bromeliads in the Parque das Dunas; f. Sampling in the central tank of Alcantarea nahoumii; g. Sampling in the central tank of Hohenbergia littoralis; h. Hose detail with algae collected from the bromeliad tanks. 
by a complex of small hills (Pioneira, Oiti, Monte Cruzeiro, Água Branca, etc.) and covers the area of approximately $22,500 \mathrm{~km}^{2}$. This area is located in the outskirts of the Atlantic Forest and the Semi-Arid Domains. Local vegetation includes rocky fields at the rocky outcrops of the top, tropical rain forest on the east slope, and "Caatinga" on the west and north (Juncá \& Borges 2002).

Parque das Dunas $\left(38^{\circ} 19^{\prime} \mathrm{W}, 12^{\circ} 55^{\prime} \mathrm{S}\right)$ is inserted in the lakes and dunes Environmental Protection Area of Abaeté, which comprises an area of about 6 million square meters enclaved in the city of Salvador, Bahia state, Brazil. The locality has great environmental importance since it represents one of the last urban remnants of dunes, lakes and "restinga" ecosystem of Brazil. Parque das Dunas vegetation is represented by the "restinga" ecosystem and the plant communities are mainly formed by herbaceous and shrub halophytes, but also by some arboreal representatives (UNIDUNAS 2015).

Material examined was collected from phytotelmata of the bromeliads Alcantarea nahoumii (Leme) J.R.Grant (Serra da Jibóia) and Hohenbergia littoralis L.B.Smith (Parque das Dunas) randomly selected in January, May, July, September, November 2015 and January 2016. The liquid material from the bromeliad tanks was collected with the aid of a 50-ml syringe coupled to a polyethylene hose. During collection of water, the abiotic features such as temperature, $\mathrm{pH}$, electric conductivity (EC) and total dissolved solids (TDS) were measured using a multiparameter probe Hanna HI98130 equipment; and dissolved oxygen (DO) measurements were performed with a portable digital equipment Instrutherm (MO-910). For each species, values minimum, maximum and mean of the water abiotic features were provided. Only the new records for Bahia and Brazil were described. Taxonomic identification of algal material was based on the specialized literature such as Komárek \& Fott (1983), Hindák (1984), Mrozinska-Webb (1985), Comas (1996), Tsarenko \& John (2011) and Pentecost (2011).

All material was analyzed using an Olympus BX43 optical microscope, and photographed with a MicroPublisher camera QImaging MP5.0-RTVCLR-10-C. After analyses, samples were preserved in Transeau solution (Bicudo \& Menezes 2006) and deposited at the Herbarium collection of the Universidade Estadual de Feira de Santana (HUEFS).

Frequency of occurrence of algae was calculated in each locality according to Matteucci $\&$ Colma (1982): $>70 \%$ - very frequent $; \leq 70 \%$ and
$>40 \%$ - frequent; $\leq 40 \%$ and $>10 \%$ - uncommon; $\leq 10 \%$ - rare.

To observe the cell wall ornamentation of Enallax costatus (Schmidle) Pascher, specimens were adhered to a glass coverslip with poly-L-lysine (Sigma, 1:10 in distilled water) to guarantee better adhesion. Cover slips with $E$. costatus attached were dehydrated in acetone series $(30,50,70,85,95$ and $100 \%, 100 \% 10 \mathrm{~min}$ each). In addition, the material was dried to critical-point in a Leica EM CPD030 apparatus; the stubs were mounted and coated with a gold layer and examined using a JEOL 6390 LV SEM.

\section{Results \& Discussion}

During the taxonomic survey of the green algae from Serra da Jibóia (rocky outcrops) and Parque das Dunas (restinga) 23 taxa were identified including three species that are mentioned for the first time for Brazil. The species already known for Bahia and their cell dimensions, figures, previous records and respective vouchers are listed in the Table 1 (Figs. 2-4).

It is important to note that all species in the present study, except for Monoraphidium contortum (Thuret) Komárková-Legnerová (Sophia 1999), are being mentioned for the first time for bromeliad phytotelmata.

Asterococcus superbus (Cienkowski) Scherffel Ber. Deutsch. Bot. Ges. 26A: 762. 1909.

Fig. 2d,e

Cells solitary or in groups of 2,4 or 8 surrounded by a stratified mucilaginous envelope, chloroplast star-shaped, one pyrenoid. Cells 11.2$17.8 \mu \mathrm{m}$ diam.

Material examined: Santa Teresinha, Serra da Jibóia, 14.I.2015, G.J.P. Ramos et al. (HUEFS 155295); 18.VII.2015, G.J.P. Ramos et al. (HUEFS 224675).

Despite of the cell diameter be smaller than reported by Pentecost (2011: 30-43 $\mu \mathrm{m}$ ) we decided to identify present specimens as Asterococcus superbus because of the presence of a stratified mucilaginous envelope, which is absent in Asterococcus limneticus G.M.Smith. According to Bicudo \& Menezes (2006), Asterococcus includes two species that are usually very seldom collected because they live in the littoral zone of stagnant water systems, and always associated with other algae and plants. In Brazil, the presence of only one Asterococcus species, A. limneticus, was recorded for Ribeirão Preto (Silva 1999) and Goiânia (Nogueira 1999). Thus, A. superbus is presently registered for the first time for Brazil. 
Table 1 - Chlorophyta species known for Bahia, their cell dimensions, figures, previous records in Bahia and herbarium vouchers (HUEFS).

\begin{tabular}{|c|c|c|c|c|}
\hline Species & Cell dimensions & Fig. & Previous records in Bahia & HUEFS \\
\hline Ankistrodesmus falcatus (Corda) Ralfs & $37.5-45 \mu \mathrm{m} \times 1.5-2 \mu \mathrm{m}$ & $2 \mathrm{a}$ & Ramos et al. (2012) & 224658 \\
\hline $\begin{array}{l}\text { Ankistrodesmus fusiformis Corda ex } \\
\text { Koršikov }\end{array}$ & $22.5-27.5 \mu \mathrm{m} \times 1.5-2.5 \mu \mathrm{m}$ & $2 b, c$ & $\begin{array}{l}\text { Fuentes et al. (2010); } \\
\text { Mendes et al. (2012); } \\
\text { Ramos et al. (2012) }\end{array}$ & $\begin{array}{l}224653,224675, \\
224698,224715\end{array}$ \\
\hline Coelastrum indicum W.B.Turner & $8.8-13.8 \mu \mathrm{m}$ & $2 \mathrm{f}, \mathrm{g}$ & $\begin{array}{l}\text { Mendes et al. (2012); } \\
\text { Ramos et al. (2015a) }\end{array}$ & $\begin{array}{l}224656,224676, \\
224696,224721\end{array}$ \\
\hline Crucigenia quadrata Morren & $4-6.5 \mu \mathrm{m} \times 2.5-3.5 \mu \mathrm{m}$ & $2 \mathrm{~h}$ & $\begin{array}{l}\text { Martins et al. (1991); } \\
\text { Fuentes et al. }(2010)\end{array}$ & 224662 \\
\hline Enallax costatus (Schmidle) Pascher & $12-18 \mu \mathrm{m} \times 8-10 \mu \mathrm{m}$ & $2 \mathrm{j}-1$ & Ramos et al. (2014) & $\begin{array}{l}224655,224677, \\
224694,224717\end{array}$ \\
\hline Monoraphidium caribeum Hindák & $12.5-18.7 \mu \mathrm{m} \times 1.5-2.5 \mu \mathrm{m}$ & $3 f$ & Ramos et al. (2012) & 224659,224716 \\
\hline $\begin{array}{l}\text { Monoraphidium contortum (Thuret) } \\
\text { Komárková-Legnerová }\end{array}$ & $10-22 \mu \mathrm{m} \times 1.5-2.5 \mu \mathrm{m}$ & $3 g$ & Ramos et al. (2012) & 224658 \\
\hline $\begin{array}{l}\text { Monoraphidium griffithii (Berkeley) } \\
\text { Komárková-Legnerová }\end{array}$ & $40-58 \mu \mathrm{m} \times 2.5-3 \mu \mathrm{m}$ & $3 \mathrm{~h}$ & Ramos et al. (2012) & $\begin{array}{l}224654,224675, \\
224698,224715\end{array}$ \\
\hline Monoraphidium komarkovae Nygaard & $61-68.8 \mu \mathrm{m} \times 1.5-2.1 \mu \mathrm{m}$ & $3 \mathrm{i}$ & $\begin{array}{l}\text { Fuentes et al. (2010); } \\
\text { Ramos et al. (2012) }\end{array}$ & 224656,224721 \\
\hline Monoraphidium subclavatum Nygaard & $25-31 \mu \mathrm{m} \times 5-6 \mu \mathrm{m}$ & $3 \mathrm{j}$ & Ramos et al. (2014) & 224662 \\
\hline Oocystis borgei J.W.Snow & $12.5-17.5 \mu \mathrm{m} \times 10-13.5 \mu \mathrm{m}$ & $4 \mathrm{~h}$ & $\begin{array}{l}\text { Martins et al. (1991); } \\
\text { Ramos et al. (2015b) }\end{array}$ & $\begin{array}{l}155295,224680, \\
224698,224714\end{array}$ \\
\hline Oocystis lacustris Chodat & $10-17.5 \mu \mathrm{m} \times \mu \mathrm{m} 7-8.5$ & $4 \mathrm{i}$ & $\begin{array}{l}\text { Martins et al. (1991); } \\
\text { Ramos et al. }(2015 b)\end{array}$ & 224676,224699 \\
\hline $\begin{array}{l}\text { Scenedesmus ecornis (Ehrenberg) } \\
\text { Chodat }\end{array}$ & $8.7-11.5 \mu \mathrm{m} \times 2.5-5 \mu \mathrm{m}$ & $4 j$ & $\begin{array}{l}\text { Fuentes et al. (2010); } \\
\text { Ramos et al. (2015a) }\end{array}$ & $\begin{array}{l}224655,224673, \\
224694,224715\end{array}$ \\
\hline Scenedesmus obtusus Meyen & $8.5-18 \mu \mathrm{m} \times 5-8.5 \mu \mathrm{m}$ & $4 \mathrm{k}, 1$ & Ramos et al. (2015a) & $\begin{array}{l}224668,224676, \\
224700,224717\end{array}$ \\
\hline $\begin{array}{l}\text { Sorastrum americanum (Bohlin) } \\
\text { Schmidle }\end{array}$ & $10-11.5 \mu \mathrm{m} \times 5-7.5 \mu \mathrm{m}$ & $4 \mathrm{~m}$ & Ramos et al. (2016) & 224656,224721 \\
\hline Sorastrum spinulosum Nägeli & $18.7-22 \mu \mathrm{m} \times 6.5-12.5 \mu \mathrm{m}$ & $4 n$ & Ramos et al. (2016) & 224662,224721 \\
\hline
\end{tabular}

Dispora speciosa Koršikov - Protococcinae: 334. 1953.

Fig. $2 \mathrm{i}$

Colonies rectangular, 4,8 or 16 groups of tetrahedral cells arranged in parallel rows; cells subglobose, asymmetric, chloroplast parietal, without pyrenoid. Cells 7.4-8.1 $\mu \mathrm{m}$ length, 5.5-7.1 $\mu$ m width.

Material examined: Santa Teresinha, Serra da Jibóia, 14.I.2015, G.J.P. Ramos et al. (HUEFS 224659); 18.VII.2015, G.J.P. Ramos et al. (HUEFS 224675);
11.IX.2015, G.J.P. Ramos et al. (HUEFS 224704); 20.XI.2015, G.J.P. Ramos et al. (HUEFS 224715).

According to Koršikov (1953), Dispora speciosa is characterized by having cells without pyrenoid arranged in rectangular colonies. The only work containing taxonomic information on Dispora speciosa in Brazil is that by Nogueira \& Oliveira (2009) based on material from Goiás state. However, after comparing the species description with the illustration in that paper (Nogueira \& 

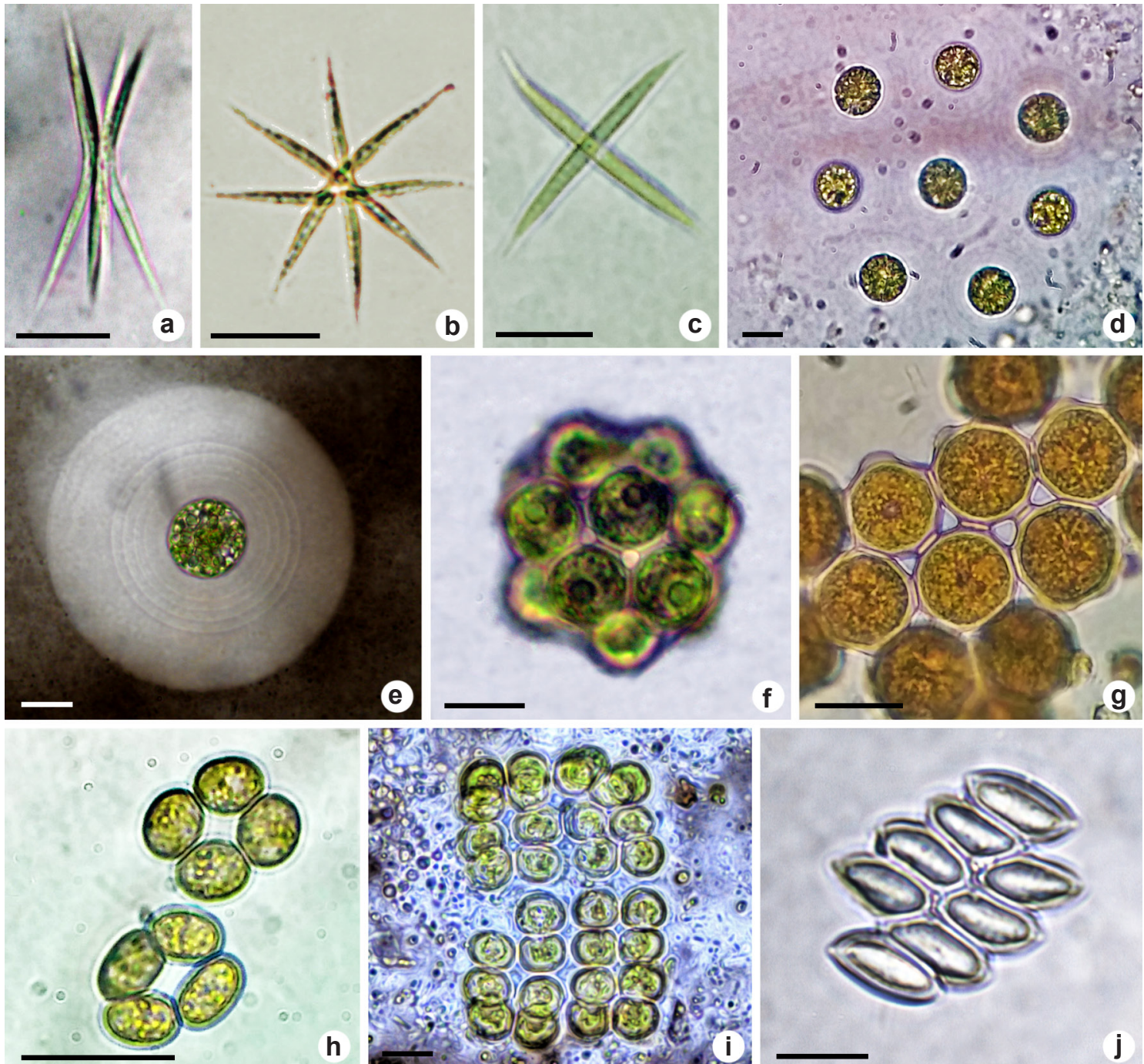

250
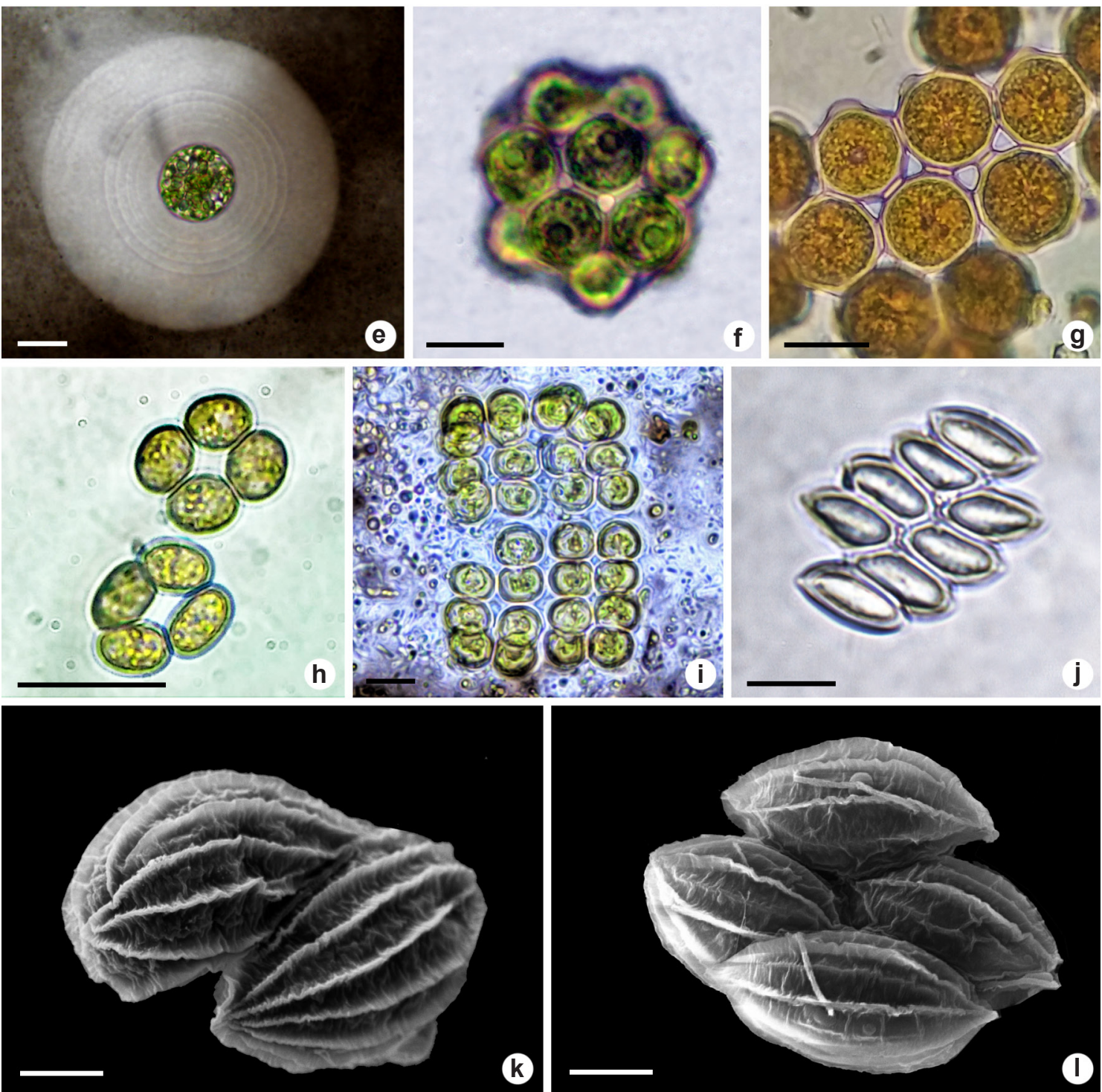

Figure 2 - a. Ankistrodesmus falcatus; b,c. A. fusiformis; d,e. Asterococcus superbus; f,g. Coelastrum indicum; h. Crucigenia quadrata; i. Dispora speciosa; j-1. Enallax costatus. (a-h. Bars $=10 \mu \mathrm{m} ; \mathrm{k}, 1$. Bars $=5 \mu \mathrm{m}$ ). 
Oliveira 2009: 138, Fig. 12) it became clear that most possibly occurred a misidentification, because the illustration refers to Dispora cuneiformis (Schimdle) Printz (see Komárek \& Fott 1983: 425, pl. 129, Fig. 4). Moreover, the latter authors mentioned that D. speciosa has pyrenoid and spherical colonies, features observed in the present material identified as D. speciosa. Thus, we consider the present the first confirmed record of D. speciosa for Brazil.

Eremosphaera viridis De Bary - Untersuch. Conjugaten. 56. 1858.

Fig. 3a-c

Cells usually solitary, spherical, sometimes colonial, in clusters of 2 or 4; cell wall smooth, thick; chloroplast parietal, several pyrenoids. Cells 23.0-32.0 $\mu \mathrm{m}$ diam.

Material examined: Santa Teresinha, Serra da Jibóia, 14.I.2015, G.J.P. Ramos et al. (HUEFS 224657); 18.VII.2015, G.J.P. Ramos et al. (HUEFS 224679); 11.IX.2015, G.J.P. Ramos et al. (HUEFS 224693); 20.XI.2015, G.J.P. Ramos et al. (HUEFS 224719).

Presence of representatives of Eremosphaera was mentioned only once for Bahia state by Fuentes et al. (2010) in a checklist prepared for Rio de Contas. However, authors gave no details such as description, cell dimensions or illustration of Eremosphaera eremosphaeria R.L.Smith \& Bold to taxonomic comparison. Thus, this is the first confirmed record of the genus for Bahia and, consequently, of $E$. viridis for the state.

Gongrosira papuasica (Borzi) Tupa - Beih. Nova Hedwigia 46: 37. 1974.

Fig. 3d

Talli formed by uniseriate filaments, with a prostrate pseudoparenchymatous system and some irregular, sparingly divided erect branches; cells cylindrical, sometimes inflated; chloroplast parietal, with one pyrenoid. Cells 7.1-14.4 $\mu \mathrm{m}$ length, 3.1-4.5 $\mu \mathrm{m}$ width.

Material examined: Salvador, Parque das Dunas, 27.I.2016, G.J.P. Ramos et al. (HUEFS 224787, HUEFS 224791, HUEFS 224794).

Gongrosira papuasica was registered only from Parque das Dunas bromeliads during the summer, after a period of some heavy rains in Salvador. The species is morphologically close to Gongrosira pseudoprostata L.R.Johnson, that is different by usually not having the erect filaments system and, when it does, they are underdeveloped (Johnson \& John 1992; John 2011).

The species is probably cosmopolitan (John 2011) occurring in England, Papua New Guinea, and Iraq. Additionally, the species was reported for North America where it was found living on the surface of vascular aquatic plants. This is the first time G. papuasica is recorded for Brazil.

Lagerheimia chodatii C.Bernard - Protococcacées et Desmidiées. 170. 1908.

Fig. 3e

Cells solitary, spherical, 4 polar spines cruciate arranged, slight arcuate; chloroplast parietal, with one pyrenoid. Cells 8.6-10.1 $\mu \mathrm{m}$ diam, spines 7.7-9.9 $\mu \mathrm{m}$ length.

Material examined: Salvador, Parque das Dunas, 27.I.2016, G.J.P. Ramos et al. (HUEFS 224795).

According Hindák (1984), Lagerheimia chodatii is the only species in the genus that has spherical cells, different from all other species that have them ellipsoid, morphologically close to those of Oocystis Nägeli ex A.Braun. Description of the present material is in accordance with those in Tsarenko \& John (2011) and Hindák (1984), although the cells identified by the latter author are slightly smaller ( $7 \mu \mathrm{m}$ diam.).

This species occurred in just one bromeliad from Parque das Dunas. According to Tsarenko \& John (2011), L. chodatii is probably cosmopolitan and widely distributed in small water bodies, what may explain its occurrence in phytotelmata. This is the first time the species is recorded for Brazil.

Oedogonium areschougii Wittrock ex K.E.Hirn Acta Soc. Sci. Fenn. 27: 270. $1900 . \quad$ Fig. 4a-c

Plant dioecious, nannandrous, gynandrosporic (?); vegetative cells cylindrical-capitellate, 54-68 $\mu \mathrm{m}$ long, 12-15.5 $\mu \mathrm{m}$ broad, apical cell with obtuse apex; oogonia solitary or in pairs, usually subglobose, opening by a median operculum, 32-40 $\mu \mathrm{m}$ diam.; oospore depressed-globose, 27-31.5 $\mu \mathrm{m}$ diam.; androsporangia not observed, dwarf males attached to oogonia, 11.4-12.5 $\mu \mathrm{m}$ long, $8-8.5 \mu \mathrm{m}$ broad, suffultory cells identical to vegetative cells.

Material examined: Santa Teresinha, Serra da Jibóia, 14.I.2015, G.J.P. Ramos et al. (HUEFS 224654); 18.VII.2015, G.J.P. Ramos et al. (HUEFS 224676); 11.IX.2015, G.J.P. Ramos et al. (HUEFS 224692); 20.XI.2015, G.J.P. Ramos et al. (HUEFS 224716).

Specimens presently identified as Oedogonium areschougii agree with both description and illustration provided by Hirn (1900), when the species proposed by Wittrock (1870) was validated. In Brazil, the first record of O. areschougii is in Hirn (1900) collected from Porto Alegre, Rio Grande do Sul state, the record 
later on referred in the checklist of algae of that state (Torgan et al. 2001). Present species was collected 115 years after Hirn (1900), and now its geographic distribution was expanded to the Northeast region of Brazil.

It was observed that in some of the samples O. areschougii was predominant, forming large masses composed of numerous filaments, and that the other green algae diversity was low. In these samples, it was common to find a large number of desmids associated to $O$. areschougii.
Oedogonium pulchrum Nordstedt \& K.E.Hirn Acta Soc. Sci. Fenn. 27: 312. $1900 . \quad$ Fig. 4d-g Plant dioecious (?), macandrous; vegetative cells cylindrical-capitellate, 20-47.2 $\mu \mathrm{m}$ long, 5.7-9.5 $\mu \mathrm{m}$ broad; oogonia 20-27 $\mu \mathrm{m}$ diam., depressed-globose, with 7-10 radial shallow, rounded projections in apical view, operculate, division inframedian, oospore globosesubglobose, 13-14 $\mu \mathrm{m}$ diam., suffultory cell often shorter than vegetative cells; androsporangia not observed.

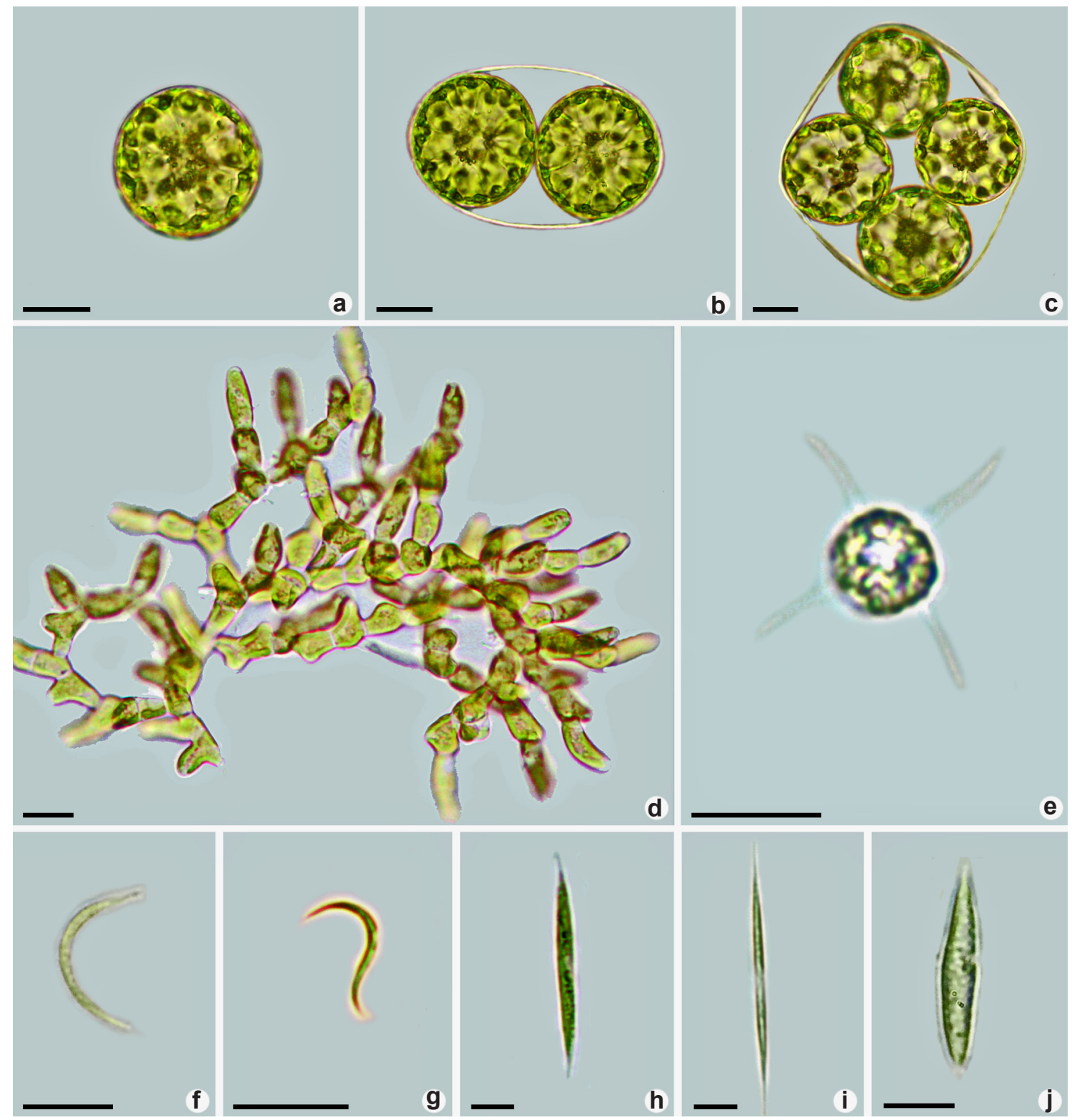

Figure 3 - a-c. Eremosphaera viridis; d. Gongrosira papuasica; e. Lagerheimia chodatii; f. Monoraphidium caribeum; g. M. contortum; h. M. griffithii; i. M. komarkovae; j. M. subclavatum; k. (Bars $=10 \mu \mathrm{m})$. 
Material examined: Salvador, Parque das Dunas, 29.I.2015, G.J.P. Ramos \& M.A. Santos (HUEFS 224739); 26.V.2015, G.J.P. Ramos et al. (HUEFS 224749); 4.IX.2015, G.J.P. Ramos et al. (HUEFS 224768); 27.I.2016, G.J.P. Ramos et al. (HUEFS 224786).

Oedogonium pulchrum was described by Nordstedt \& K.E.Hirn from material collected at Pirassununga, São Paulo state (Hirn 1900). The species is being recorded again in Brazil 117 years after its proposition. Morphologically, O. pulchrum resembles $O$. itzigsohnii, however, the latter species differs by having projections (usually conical) more elongated round the oogonia (MrozinskaWebb 1985).

Despite of being little reported in the literature, O. pulchrum was very common in this study and restricted to Parque das Dunas, occurring in most of Hohenbergia littoralis plants forming large green masses in the central rosette as well as on the side leaves. Presence of numerous oospores is most probably related to some survival strategy due the low rainfall precipitation during certain periods of the year.
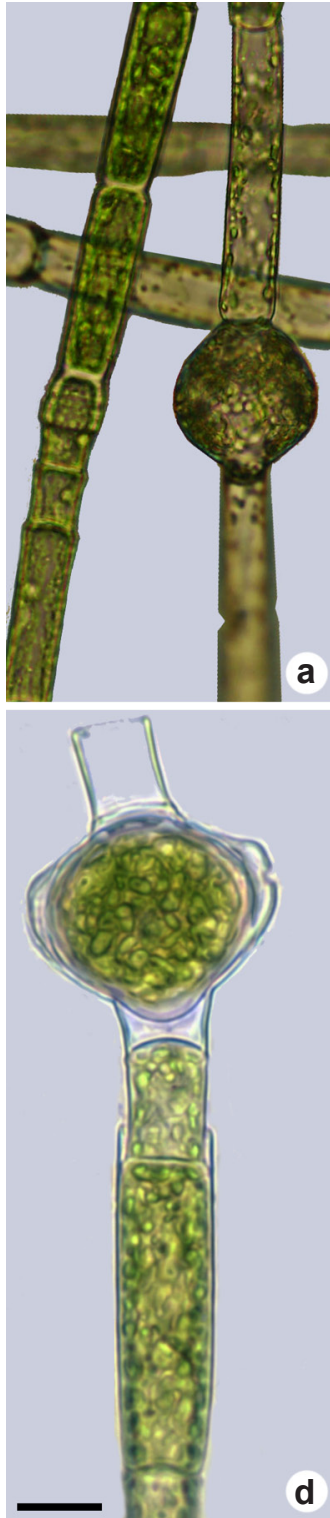

d

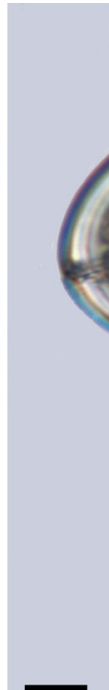

$-$
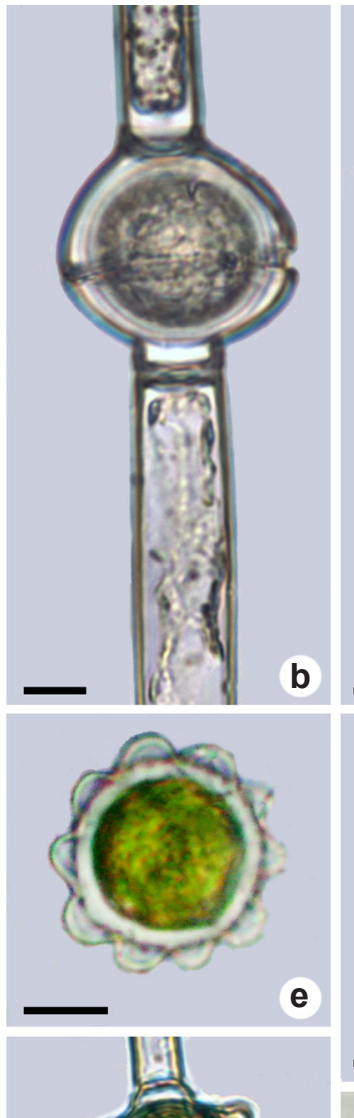

b
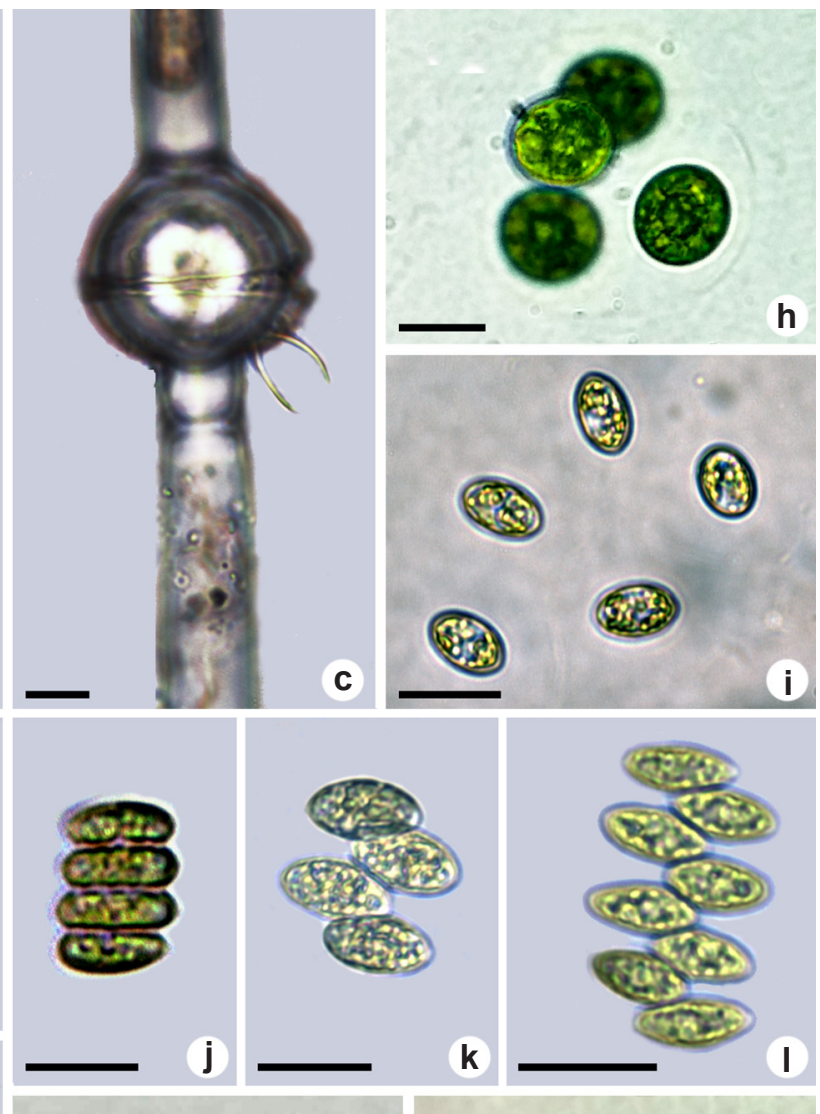

i

Figure 4 - a-c. Oedogonium areschougii; d-g. O. pulchrum; h. Oocystis borgei; i. O. lacustris; j. Scenedesmus ecornis; k,1. S. obtusus; m. Sorastrum americanum; n. S. spinulosum. (Bars $=10 \mu \mathrm{m})$. 
In addition, $O$. pulchrum was a well-adapted species to large variation of dissolved oxygen, but under low DO concentration $\left(<4 \mathrm{mg} \mathrm{L}^{-1}\right)$ it was more common to find oospores than in the more oxygenated tanks ( $\mathrm{DO}<7 \mathrm{mg} \mathrm{L}^{-1}$ ), where it was more frequent to find sterile filaments.

Several factors may affect the spatial distribution pattern of bromeliads, among which are the reproductive mechanism adopted by the plant (Crawley \& May 1987), substrate type (Fischer 1994), as well as light, temperature and humidity. The bromeliads of the two areas studied live in different conditions, i.e. Hohenbergia littoralis inhabits an area of sandbank dunes ("restinga" area) near the sea level, whereas Alcantarea nahoumii occupies an area of rocky outcrops, stony substrate, at an altitude of 850 $\mathrm{m}$. Despite of these differences of environmental conditions, both bromeliads accumulate sufficient amount of water, leading to the development of algae, including chlorophytes.

Freshwater chlorophytes may be represented by unicellular to filamentous forms. In the present study, there was a prevalence of coenobial/ colonial (10 species), followed by coccoid (8), filamentous (2) and pseudoparenchymatous thalli (Gongrosira papuasica). The most representative genus in number of species during this study was Monoraphidium with five. Apart from Oedogonium, the other chlorophytes had their occurrence restricted to one of the two areas studied.

Comparison of the green algae diversity of both areas allowed observing that the bromeliads from Serra da Jibóia showed a greater taxonomic richness (20 taxa) in relation to that of Parque das Dunas (3 taxa). However, all taxa recorded for the last area were considered rare (Oedogonium pulchrum, recollected in Brazil after 115 years of its original description) and new occurrences for Brazil (Gongrosira papuasica and Lagerhemia chodatti). At Serra da Jibóia, Oedogonium areschougii (recorded 116 years after its first report of occurrence in the country) and Dispora speciosa (first confirmed record for Brazil) were highlighted. Eremosphaera viridis is presently reported for the first time for Bahia state.

Analysis of the taxa studied distribution according to their frequency of occurrence showed the prevalence of rare taxa (12) followed by the uncommon (7) and the frequent taxa (3) (Tab. 2). Among all species identified, the most common found in bromeliads from Serra da Jibóia was
Enallax costatus, which was considered a frequent taxon $(\mathrm{F}=65 \%)$, whereas at Parque das Dunas the leading species was Oedogonium pulchrum with a frequency of occurrence over $80 \%$.

Regarding the abiotic features measured in the bromeliad tanks, water $\mathrm{pH}$ was dominantly acidic in both studied areas (Serra da Jibóia 5.9 \pm 0.6 ; Parque das Dunas $4.3 \pm 0.6$ ), as typical this kind of environment (Laessle 1961; Kitching 2000; Guimarães-Souza et al. 2006), although some species recorded for Serra da Jibóia as Eremosphaera viridis, Monoraphidium griffithii, Scenedesmus ecornis, S. obtusus and Coelastrum indicum also occurred in tanks with slightly alkaline condition (pH 7.6) (Tab. 3). Coccoid green algae prevailed in alkaline and neutral waters; however, they can also grow in acidic waters (Philipose 1967; Comas 1996).

Overall, conductivity in the bromeliad tanks was considered higher $\left(0.22 \pm 0.16 \mathrm{mS} \mathrm{cm}^{-1}\right)$ in the Serra da Jibóia bromeliads compared to those of Parque das Dunas $\left(0.07 \pm 0.09 \mathrm{mS} \mathrm{cm}^{-1}\right)$, despite the fact of the latter area be located closer to the sea. These values are near those reported by Sophia et al. (2004) and Guimarães-Souza et al. (2006) for bromeliad tanks exposed to the sun located in the "restinga" of the Jurubatiba National Park, Macaé, Rio de Janeiro state. Acidification produced by the bromeliads, besides the low conductivity could be relevant factors acting on the selection of the community colonization (Lopez et al. 2009), and most probably contributed for the development of green algae in the tanks.

High temperature is another favorable condition for development of green algae in general, mainly of coccoid species (Philipose 1967; Sant'Anna \& Martins 1982; Comas 1996). The water temperature in the bromeliad tanks was mostly considered high reaching $34.9^{\circ} \mathrm{C}$ (Serra da Jibóia $27 \pm 2.9^{\circ} \mathrm{C}$, Parque das Dunas $30.3 \pm 2.1$ $\left.{ }^{\circ} \mathrm{C}\right)$. Gongrosira papuasica, Lagerheimia chodatii and Oedogonium pulchrum were recorded present in bromeliads from Parque das Dunas growing at an average temperature $>30^{\circ} \mathrm{C}$, while Monoraphidium contortum was the only species of the Serra da Jibóia found growing under these conditions.

Dissolved Oxygen (DO) is also an important factor for the phytotelmata community dynamics, and their regimens are influenced by the presence or absence of algae which, in turn reflects the position of the plant with respect to sun or shade (Laessle 1961; Kitching 2000). As the bromeliads of two areas were exposed to the sun, DO concentration 
Table 2 - Distribution, frequency (F) and classification (C) of Chlorophyta species in two areas of the Bahia state. $\mathrm{VF}=$ very frequent; $\mathrm{F}=$ frequent; $\mathrm{U}=$ uncommon; $\mathrm{R}=$ rare.

\begin{tabular}{|c|c|c|c|c|c|c|c|c|c|c|}
\hline \multirow{3}{*}{ Species } & \multirow{2}{*}{\multicolumn{4}{|c|}{$\begin{array}{c}\text { Serra da Jibóia } \\
2015\end{array}$}} & \multicolumn{4}{|c|}{ Parque das Dunas } & \multirow{3}{*}{ F (\%) } & \multirow{3}{*}{$\mathbf{C}$} \\
\hline & & & & & \multirow[b]{2}{*}{ jan } & \multicolumn{2}{|l|}{2015} & \multirow{2}{*}{$\begin{array}{c}2016 \\
\text { jan }\end{array}$} & & \\
\hline & jan & jul & sep & nov & & may & sep & & & \\
\hline Oedogonium pulchrum & & & & & $\mathrm{x}$ & $\mathrm{x}$ & $\mathrm{x}$ & $\mathrm{x}$ & 85 & VF \\
\hline Enallax costatus & $\mathrm{x}$ & $\mathrm{x}$ & $\mathrm{x}$ & $\mathrm{x}$ & & & & & 65 & $\mathrm{~F}$ \\
\hline Eremosphaera viridis & $\mathrm{x}$ & $\mathrm{x}$ & $\mathrm{x}$ & $\mathrm{x}$ & & & & & 48.75 & $\mathrm{~F}$ \\
\hline Coelastrum indicum & $\mathrm{x}$ & $\mathrm{x}$ & $\mathrm{x}$ & $\mathrm{x}$ & & & & & 42.5 & $\mathrm{~F}$ \\
\hline Monoraphidium griffithii & $\mathrm{x}$ & $\mathrm{x}$ & $\mathrm{x}$ & $\mathrm{x}$ & & & & & 30 & $\mathrm{U}$ \\
\hline Oedogonium areschougii & $\mathrm{x}$ & $\mathrm{x}$ & $\mathrm{x}$ & $\mathrm{x}$ & & & & & 26.25 & $\mathrm{U}$ \\
\hline Ankistrodesmus fusiformis & $\mathrm{x}$ & $\mathrm{x}$ & $\mathrm{x}$ & $\mathrm{x}$ & & & & & 20 & $\mathrm{U}$ \\
\hline Scenedesmus obtusus & $\mathrm{x}$ & $\mathrm{x}$ & $\mathrm{x}$ & $\mathrm{x}$ & & & & & 18.75 & $\mathrm{U}$ \\
\hline Oocystis borgei & $\mathrm{x}$ & $\mathrm{x}$ & $\mathrm{x}$ & $\mathrm{x}$ & & & & & 15 & $\mathrm{U}$ \\
\hline Oocystis lacustris & & $\mathrm{x}$ & $\mathrm{x}$ & & & & & & 12.5 & $\mathrm{U}$ \\
\hline Scenedesmus ecornis & $\mathrm{x}$ & $\mathrm{x}$ & $\mathrm{x}$ & $\mathrm{x}$ & & & & & 11.25 & $\mathrm{U}$ \\
\hline Dispora speciosa & $\mathrm{x}$ & $\mathrm{x}$ & $\mathrm{x}$ & $\mathrm{x}$ & & & & & 6.25 & $\mathrm{R}$ \\
\hline Monoraphidium caribeum & $\mathrm{x}$ & & & $\mathrm{x}$ & & & & & 5 & $\mathrm{R}$ \\
\hline Asterococcus superbus & $\mathrm{x}$ & $\mathrm{x}$ & & & & & & & 3.75 & $\mathrm{R}$ \\
\hline Gongrosira papuasica & & & & & & & & $\mathrm{x}$ & 3.75 & $\mathrm{R}$ \\
\hline Monoraphidium komarkovae & $\mathrm{x}$ & & & $\mathrm{x}$ & & & & & 3.75 & $\mathrm{R}$ \\
\hline Sorastrum americanum & $\mathrm{x}$ & & & $\mathrm{x}$ & & & & & 3.75 & $\mathrm{R}$ \\
\hline Monoraphidium subclavatum & $\mathrm{x}$ & & & & & & & & 2.5 & $\mathrm{R}$ \\
\hline Sorastrum spinulosum & $\mathrm{x}$ & & & $\mathrm{x}$ & & & & & 2.5 & $\mathrm{R}$ \\
\hline Monoraphidium contortum & $\mathrm{x}$ & & & & & & & & 2.5 & $\mathrm{R}$ \\
\hline Ankistrodesmus falcatus & $\mathrm{x}$ & & & & & & & & 1.25 & $\mathrm{R}$ \\
\hline Crucigenia quadrata & $\mathrm{x}$ & & & & & & & & 1.25 & $\mathrm{R}$ \\
\hline Lagerheimia chodatii & & & & & & & & $\mathrm{x}$ & 1.25 & $\mathrm{R}$ \\
\hline
\end{tabular}

was primarily high (Serra da Jibóia $7.8 \pm 3.7 \mathrm{mg}$ $\mathrm{L}^{-1}$, Parque das Dunas $6.8 \pm 3.9 \mathrm{mg} \mathrm{L}^{-1}$ ). The main species often found in conditions of high dissolved oxygen concentration (DO mean values $>8 \mathrm{mg}$ $\mathrm{L}^{-1}$ ) were Coelastrum indicum, Oocystis borgei, $O$. lacustris and Oedogonium areschougii.

Rainfall precipitation influenced water accumulation in the bromeliad tanks in both areas of present study, so that the lack of rain between October and December 2015 at Parque das Dunas (a less rainy area in the Salvador region) did not allow formation of an algal community. During the same period at Serra da Jibóia it was observed a water volume significant decline; however, completely dry bromeliads in the area were seldom found. This was possibly due to the local environmental conditions (high altitude and high humidity brought through the woods surrounding the Serra da Jibóia) that tends to maintain some humidity regularity for the phytotelmata community to establish.

The bromeliads leaf morphology and architecture may also be considered relevant features for the establishment of phytotelmata communities (Laessle 1961; Kitching 2000; Marino et al. 2011), provided that different bromeliad species can shape their algal community diversity 
Table 3 - Amplitude of environmental variables in which each species of Chlorophyta occurred in the bromeliad tanks from two areas of Bahia state. $\mathrm{T}=$ Water temperature; $\mathrm{C}=$ Conductivity; $\mathrm{TDS}=$ Total Dissolved Solids; $\mathrm{DO}=\mathrm{Dissolved}$ Oxygen.

\begin{tabular}{|c|c|c|c|c|c|}
\hline Species & $\mathrm{T}\left({ }^{\circ} \mathrm{C}\right)$ & pH & $\mathrm{C}\left(\mathrm{mS} . \mathrm{cm}^{-1}\right)$ & TDS (ppt) & DO (mg.. $\left.{ }^{-1}\right)$ \\
\hline Ankistrodesmus falcatus & 29.8 & 5.7 & 0.4 & 0.15 & 4.1 \\
\hline Ankistrodesmus fusiformis & $21.8-32.3(28.7)^{*}$ & $5.1-6.7(5.9)^{*}$ & $0.03-0.55(0.2)^{*}$ & $0.01-0.6(0.14)^{*}$ & $2.9-13.1(5.9)^{*}$ \\
\hline Asterococcus superbus & $21.6-30.2(27)$ & $5.5-5.7(5.6)$ & $0.07-0.39(0.27)$ & $0.04-0.2(0.14)$ & $3.5-6.6(5.4)$ \\
\hline Coelastrum indicum & $22.2-32.9(27.4)$ & $4.8-7.6(6)$ & $0.04-0.68(0.14)$ & $0.04-0.2(0.14)$ & $3.4-23.5(8.3)$ \\
\hline Crucigenia quadrata & 27.5 & 6.2 & 0.33 & 0.11 & 4.6 \\
\hline Dispora speciosa & $21.6-30.7(27.9)$ & $5.3-6.6(6)$ & $0.07-0.68(0.3)$ & $0.04-0.6(0.2)$ & $3.4-23.5(7.1)$ \\
\hline Enallax costatus & $21.8-32.9(27.6)$ & $4.3-6.9(5.9)$ & $0.04-0.68(0.25)$ & $0.02-0.6(0.13)$ & $2.9-18.9(7.3)$ \\
\hline Eremosphaera viridis & $21.7-32.3(26.9)$ & $3.5-7.6(5.8)$ & $0.03-0.65(0.23)$ & $0.01-0.6(0.12)$ & $3.4-13.9(7.5)$ \\
\hline Gongrosira papuasica & $29.6-31.8(30.6)$ & $3.9-4(4)$ & $0.04-0.12(0.07)$ & $0.02-0.6(0.4)$ & $3.8-11.0(7.9)$ \\
\hline Lagerheimia chodatii & 31.4 & 4.1 & 0.03 & 0.02 & 1.3 \\
\hline Monoraphidium caribeum & $27.2-30.7(29.1)$ & $5.5-6.2(5.9)$ & $0.09-0.37(0.23)$ & $0.05-0.6(0.2)$ & $3.4-11.4(5.9)$ \\
\hline Monoraphidium contortum & $29.8-30.7(30.2)$ & $5.6-6.0(5.8)$ & $0.13-0.39(0.26)$ & $0.15-0.60(0.37)$ & $3.5-4.1(3.8)$ \\
\hline Monoraphidium griffithii & $21.7-32.3(26.9)$ & $3.5-7.6(5.8)$ & $0.03-0.65(0.23)$ & $0.01-0.6(0.12)$ & $3.4-13.9(7.5)$ \\
\hline Monoraphidium komarkovae & $27.4-31(29.8)$ & $5.8-6.3(6)$ & $0.1-0.55(0.3)$ & $0.12-0.6(0.26)$ & $3.5-5.9(4.8)$ \\
\hline $\begin{array}{l}\text { Monoraphidium } \\
\text { subclavatum }\end{array}$ & $27.5-30.7(29.1)$ & $6.0-6.2(6.1)$ & $0.13-0.33(0.23)$ & $0.11-0.6(0.35)$ & $3.5-4.6(4)$ \\
\hline Oedogonium areschougii & $22-31(26.8)$ & $4.6-6.6(5.7)$ & $0.04-0.68(0.2)$ & $0.02-0.34(0.09)$ & $3.5-23.5(8.1)$ \\
\hline Oedogonium pulchrum & $26.2-34.9(30.4)$ & $3.2-6.3(4.3)$ & $0.0-0.48(0.07)$ & $0.0-0.24(0.03)$ & $1.7-23.6(7.3)$ \\
\hline Oocystis borgei & $21.7-30.2(26)$ & $3.5-6.7(5.8)$ & $0.08-0.65(0.25)$ & $0.04-0.33(0.12)$ & $2.9-23.5(9.3)$ \\
\hline Oocystis lacustris & $22.0-29.7(25)$ & $3.8-5.5(4.7)$ & $0.01-0.23(0.08)$ & $0.0-0.11(0.11)$ & $5.6-13.2(9)$ \\
\hline Scenedesmus ecornis & $21.7-32(26.9)$ & $3.5-7.6(5.9)$ & $0.09-0.68(0.36)$ & $0.18-0.34(0.18)$ & $2.9-13.2(7.1)$ \\
\hline S. obtusus & $21.8-32.9(25.7)$ & $3.5-7.6(6)$ & $0.04-0.68(0.29)$ & $0.02-0.34(0.14)$ & $2.9-13.6(7.7)$ \\
\hline Sorastrum americanum & $27.4-30.3(29.1)$ & $5.8-6.3(6)$ & $0.1-0.43(0.27)$ & $0.12-0.21(0.2)$ & $4.5-5.9(5.2)$ \\
\hline S. spinulosum & $27.4-29.9(28.4)$ & $5.8-6.3(6.1)$ & $0.22-0.43(0.32)$ & $0.11-0.21(0.15)$ & $4.3-5.9(5)$ \\
\hline
\end{tabular}

*Mean values are shown in parentheses.

(Carrias et al. 2014). In the present study, it was observed that the algal community species richness was greater in Alcantarea nahoumii (bromeliad from Serra da Jibóia), probably also due to an increased water retention promoted by the great number of leaves (up to 56) that contributed to the formation of more tanks. On the other hand, the leaf architecture of Hohenbergia littoralis (bromeliad from Parque das Dunas) probably influenced the low richness of taxa, since the plant has fewer leaves (up to 24), usually more grouped, providing a large accumulation of water in the central tank and much less in the side leaves.

Thus, a combined analysis of abiotic variables of water, bromeliad's position (shade or sun) and plant architecture is essential to understand the patterns of algal community in phytotelmata environments. Finally, more floristic studies of the algae living in phytotelmata (bromeliads and/ or another plants) are needed not only to expand the knowledge of the green algae, but also of other groups, because it is probably that other rare species will occur in these microcosms.

\section{Acknowledgments}

We are grateful to CNPq ("Conselho Nacional de Desenvolvimento Científico e Tecnológico") and FAPESB ("Fundação de Amparo à Pesquisa do estado da Bahia", Project "Flora da Bahia", Process № 483909/2012) for partial financial support; to Camila dos Anjos Ribeiro, Maria Aparecida dos Santos and Daniela da Silva Reis for their precious 
assistance during sample collections. We also thank FAPESB for fellowship given to GJP Ramos (Process No BOL0513/2014).

\section{References}

Bicudo CEM \& Menezes M (2006) Gêneros de algas de águas continentais do Brasil: chave para identificação e descrições. $2^{\text {a }}$ ed. RiMa, São Carlos. 502p.

Brouard O, Lejeune AH, Leroy C, Cereghino R, Roux O, Pelozuelo L, Dejean A, Corbara B \& Carrias JF (2011) Are algae relevant to the detritus based food web in tank-bromeliads? PLoS ONE 6: e20129.

Carrias JF, Céréghino R, Brouard O, Pelozuelo L, Dejean A, Couté A, Corbara B \& Leroy C (2014) Two coexisting tank bromeliads host distinct algal communities on a tropical inselberg. Plant Biology 16: 997-1004.

Comas GA (1996) Las Chlorococcales dulciacuícolas de Cuba. Bibliotheca Phycologica, J. Cramer, Berlin. 192 p.

Crawley MJ \& May RM (1987) Population dynamics and plant community structure: competition between annuals and perennials. Journal of Theoretical Biology 125: 475-489.

Fischer EA (1994) Polinização, fenologia e distribuição espacial de Bromeliaceae numa comunidade de Mata Atlântica, litoral sul de São Paulo. Master's Thesis. Universidade Estadual de Campinas, Campinas. 80p.

Fuentes EV, Oliveira HSB, Cordeiro-Araújo MK, Severi W \& Moura AN (2010) Variação espacial e temporal do fitoplâncton do Rio de Contas, Bahia, Brasil. Revista Brasileira de Engenharia de Pesca 5: 13-25.

Guimarães-Souza BA, Mendes GM, Bento L, Marotta H, Santoro AL, Esteves FA, Pinho L, Farjalla VF \& Enrich-Prast A (2006) Limnological parameters in the water accumulated in tropical bromeliads. Acta Limnologica Brasiliensia 18: 47-53.

Hernández-Rodríguez B, Estrada-Vargas L \& Novelo E (2014) Las microalgas de Tillandsia multicaulis Steud. (Bromeliaceae) de la Reserva Ecológica "La Martinica", Veracruz. TIP Revista Especializada en Ciencias Químico-Biológicas 17: 117-125.

Hindák F (1984) Studies on the chlorococcal algae (Chlorophyceae) III. Biologické Práce 30: 1-312.

Hirn KE (1900) Monographie und iconographie der Oedogoniaceen. Acta Societatis Scientiarum Fennicae 27: 1-394.

John DM (2011) Phylum Chlorophyta. Orders Chaetophorales, Microsporales, Ulotrichales. In: John DM, Whitton BA, AJ Brook (eds.). The freshwater algal flora of the British Isles. An identification guide to freshwater and terrestrial algae. $2^{\text {nd }}$ ed. Cambridge University Press, Cambridge. Pp. 524-554.

Johnson LR \& John DM (1992) Taxonomic observations on some uncommon and new Gongrosira species (Chaetophorales sensu stricto, Division
Chlorophyta). British Phycological Journal 27: 153-163.

Juncá FA \& Borges CLS (2002) Fauna associada a bromélias terrícolas da Serra da Jibóia, Bahia. Sitientibus Série Ciências Biológicas 2: 73-81.

Killick SA, Blanchon DJ \& Large MF (2014) Algal communities in phytotelmata: a comparison of native Collospermum and exotic bromeliads (Monocotyledonae) in New Zealand. Telopea 17: 303-310.

Kitching RL (2000) Food webs and container habitats the natural history and ecology of phytotelmata. Cambridge University Press, Cambridge. 429p.

Komárek J \& Fott B (1983) Chlorophyceae Chlorococcales. In: Huber-Pestalozzi G (ed.) Das phytoplankton des süsswassers: systematic und biologie. E. Schweizerbart'sche Verlagsbuchhandling (Nägele u. Obermiller), Stuttgart. Pp. 1-1044.

Koršikov AA (1953) Viznachnik prisnovodnihk vodorostey Ukrainsykoi RSR [Vyp] V. Pidklas Protokokovi (Protococcineae). Bakuol'ni (Vacuolales) ta Protokokovi (Protococcales) [The freshwater algae of the Ukrainian SSR. V. sub-class Protococcineae. Vacuolales and Protococcales]. Akad. Nauk URSR, Kyjv [Kiev]. 439p.

Laessle AM (1961) A micro-limnological study of jamaican bromeliads. Ecology 42: 499-517.

Lawton J (1983) Plant architecture and the diversity of phytophagous insects. Annual Review of Entomology 28: 23-39.

Lopez LCS, Alves RRN \& Rios RI (2009) Microenvironmental factors and the endemism of bromeliad aquatic fauna. Hydrobiologia 625: 151-156.

Lyra LT (1976) Microflora de bromeliáceas do estado de Pernambuco, Brasil. Memórias do Instituto Oswaldo Cruz 4: 37-50.

Marino NAC, Guariento RB, Dib V, Azevedo FD \& Farjalla VF (2011) Habitat size determine algae biomass in tank-bromeliads. Hydrobiologia 678: 191-199.

Martins DV, Sant'Anna CL \& Oliveira OC (1991) Estudo qualitativo do fitoplâncton do Dique do Tororó, Salvador, Bahia, Brasil. Revista Brasileira de Biologia 51: 445-453.

Matteucci SD \& Colma A (1982) Metodologia para el estúdio de la vegetación. The General Secretarial of the Organization of American States, Washington. $167 \mathrm{p}$.

Mendes MCQ, Colma A, Menezes M, Nunes JMC, Pereira S \& Nascimento IA (2012) Coleção de microalgas de ambientes dulciaquícolas naturais da Bahia, Brasil, como potencial fonte para a produção de biocombustíveis: uma abordagem taxonômica. Acta Botanica Brasilica 26: 691-696.

Mrozinska-Webb T (1985) Chlorophyta VI. Oedogoniophyceae: Oedogoniales. In: Ettl H, Gerloff J, Heynig H \& Mollenhauer D (eds.) 
Süsswasserflora von Mitteleuropa. Band 14. Gustav Fischer Verlag, Stuttgart, New York. Pp. 1-624.

Nogueira IS (1991) Primeiro registro de ocorrência de Scotiellopsis terrestris (Chlorellales, Chorellaceae) em ambiente fitotélmico tropical. Revista Brasileira de Biologia 51: 437-444.

Nogueira IS (1999) Estrutura e dinâmica da comunidade fitoplanctônica da represa Samambaia, Goiás, Brasil. PhD Thesis. Universidade de São Paulo, São Paulo. 341p.

Nogueira IS \& Oliveira JE (2009) Chlorococcales e Ulothricales de hábito colonial de quatro lagos artificiais do município de Goiânia - GO. Iheringia, Série Botânica 64: 123-143.

Oliveira MGN \& Rocha CFD (1997) O efeito da complexidade da bromélia-tanque Neoregelia cruenta (R.Graham) L.B. Smith sobre a comunidade animal associada. Bromélia 4: 13-22.

Pentecost A (2011) Phylum Chlorophyta. Order Tetrasporales. In: John DM, Whitton BA \& Brook AJ (eds.). The freshwater algal flora of the British Isles. An identification guide to freshwater and terrestrial algae. $2^{\text {nd }}$ ed.. Cambridge University Press, Cambridge. Pp. 376-380.

Philipose MT (1967) Chlorococcales. Indian Council of Agricultural Research, New Delhi. 365p.

Picado C (1913) Les broméliacées épiphytes considérées comme milieu biologique. Bulletin Scientifique France et Belgique 47: 215-360.

Ramos GJP, Bicudo CEM, Góes-Neto A \& Moura CWN (2012) Monoraphidium and Ankistrodesmus (Chlorophyceae, Chlorophyta) from Pantanal dos Marimbus, Chapada Diamantina, Bahia state, Brazil. Hoehnea 39: 421-434.

Ramos GJP, Bicudo CEM, Góes-Neto A \& Moura CWN (2014) New additions of coccoid green algae to the phycoflora of Brazil and the Neotropics. Acta Botanica Brasilica 28: 8-16.

Ramos GJP, Bicudo CEM, Góes-Neto A \& Moura CWN (2016) Hydrodictyaceae (Chlorophyceae, Chlorophyta) do Pantanal dos Marimbus, Chapada Diamantina, Bahia, Brasil. Iheringia, Série Botânica 71: 1-9.
Ramos GJP, Bicudo CEM \& Moura CWN (2015a) Scenedesmaceae (Chlorophyta, Chlorophyceae) de duas áreas do Pantanal dos Marimbus (Baiano e Remanso), Chapada Diamantina, estado da Bahia, Brasil. Hoehnea 42: 549-566.

Ramos GJP, Bicudo CEM \& Moura CWN (2015b) Trebouxiophyceae (Chlorophyta) do Pantanal dos Marimbus, Chapada Diamantina, Bahia, Brasil. Iheringia, Série Botânica 70: 57-72.

Rocha CFD, Cogliatti-Carvalho L, Almeida DR \& Freitas AFN (1997) Bromélias: ampliadoras da biodiversidade. Bromélia 4: 7-10.

Sant'Anna CL \& Martins DV (1982) Chlorococcales (Chlorophyceae) dos Lagos Cristalino e São Sebastião, Amazonas, Brasil: taxonomia e aspectos limnológicos. Revista Brasileira de Botânica 5: 67-82.

Silva LHS (1999) Fitoplâncton de um reservatório eutrófico (Lago Monte Alegre), Ribeirão Preto, São Paulo, Brasil. Revista Brasileira de Biologia 59: 281-303.

Sophia MG (1999) Desmídias de ambientes fitotélmicos bromelícolas. Revista Brasileira de Biologia 59: 141-150.

Torgan LC, Barreda KA \& Fortes DF (2001) Catálogo das algas Chlorophyta de águas continentais e marinhas do Rio Grande do Sul, Brasil. Iheringia, Série Botânica 56: 147-183.

Tsarenko PM \& John DM (2011) Phylum Chlorophyta (Green Algae) Order Sphaeropleales. In: John DM, Whitton BA \& Brook AJ (eds.). The freshwater algal flora of the British Isles. An identification guide to freshwater and terrestrial algae. $2^{\text {nd }}$ ed. Cambridge University Press, Cambridge. Pp. 461-465.

UNIDUNAS (2015) Universidade Livre das Dunas e Restinga de Salvador. Available at $<$ http://www. unidunas.com.br/flora $>$. Access on 3 September 2015.

Varga L (1928) Ein interessanter biotop ther biocönose von wasserorganismen. Biologisches Zentralblatt 48: $143-162$.

Wittrock VB (1870) Dispositio Oedogoniacearum suecicarum. Öfversigt af Kongl. Vetenskaps.Akademiens Förhandlingar, Stockholm 27: 119144. 